\title{
Pieni ja suuri kirja pienestä ja suuresta teosta
}

Juha Suoranta (2010). Piilottajan päiväkirja. Into-pamfletti, Like Kustannus.

\begin{abstract}
A ikuiskasvatuksen professori Juha Suoranta on kirjoittanut mainion kirjan omasta moraalisesta ratkaisustaan, päätöksestään auttaa hätään joutunutta tuntematonta ihmistä, ja ratkaisun seurauksista.

Tarina on vajaan puolen vuoden ajalle, maaliskuusta elokuuhun 2009 ulottuva päiväkirja. Se alkaa yllättävästä sähköpostiviestistä. Suorannalle kerrotaan afgaaninuorukaisesta, joka on hakenut turvapaikkaa Suomesta ja jota ollaan kyseenalaisin perustein juuri käännyttämässä pois, täysin turvattomiin oloihin. Aikaa on vähän ja kun selviää, että virallisten rakenteiden suhteen ei mitään ole enää niin nopeasti tehtävissä, Suoranta päättää toimia itse ja piilottaa pojan sukulaiseltaan tyhjäksi jääneeseen asuntoon.
\end{abstract}

Kirjoittaja käy valtaisalla tarmollaan selvittämään tuon alaikäisen Ashrafin tilannetta. Hän ottaa yhteyttä viranomaisiin, kirkollisiin piireihin, auttamistyötä tekeviin järjestöihin, mediaan, kollegoihin, ystäviin. Hän järjestelee asioita ja ne lähteväkin sujumaan niin, että käännyttämiseli karkoituspäätöksen toimeenpano keskeytetään ensin väliaikaisesti ja sitten Ashraf saa turvapaikanhakijan aseman Suomessa. Tarinan loppuessa nuori mies on saanut myös koulutuspaikan ja sen taas toivotaan johtavan oleskeluluvan saamiseen. Suoranta voi lopettaa vastuun- kantamisensa huojentunein mielin.

Tästä kaikesta Suoranta on kirjoittanut sivumäärältään pienen, mutta tavattoman monikerroksisen, sisällyksekkään ja kokonaisuutena hallitun tekstin. Päiväkirjamuoto on tietysti luontevakin tällaisessa tapauksessa, joka on selväpiirteinen, tietystä ajankohdasta alkava ja myös päättyvä prosessi. Mutta päiväkirjamuoto on myös tavattoman hyvä kirjoittamisen väline, sillä se juuri mahdollistaa monenlaisten tasojen, ainesten ja assosiaatioidenkin kuljettamiseen tekstissä. Päiväkirja on eräs esseistiikan laji ja tämä kirja todella upea näyte päiväkirjamuodon käyttelystä.

\section{Moraali, uskonto, suomalaisuus}

Yksi taso on suomalaisen yhteiskunnan, viranomaiskäytäntöjen ja myös tällä hetkellä vallitsevan henkisen ilmapiirin kuvaus. Ashrafin tapaukseen ei liittynyt suuria skandaaleja tai vääryyksiä, ja yhteiskunta pohjimmiltaan toimii sittenkin varsin hyvin. Ulkopuolelta tulijalle se kuitenkin voi näyttäytyä eräänlaisena linnakkeena, ja monta perusasiaa täytyy järjestää kuntoon ennen kuin yhteiskuntaan ja myös sen tarjoamiin etuihin todella pääsee sisään. Myös liiallinen turvautuminen pelkkään lain kirjaimeen näyttäytyy Suorannan mukaan ongelmana. Ihmiset kyllä tarkoittavat hyvää, mutta omakohtaista rohkeutta tarttua asioihin ei ehkä ole tarpeeksi.

Toisaalta kirja on hyvin henkilökohtainen. Suoranta kuvaa tarkoin itseään, omaa epävarmuuttaan ja epätietoisuuttaan joutuessaan nopean päätöksensä vuoksi aivan uusiin, tarkkaa perehtymistä vaativiin ympyröihin. Hän haluaa auttaa ja pysyy koko ajan selkeästi ratkaisunsa takana, mutta helppoa se ei ole. Avuliaisuudessaankin Suoranta haluaa samalla säilyttää henkilökohtaisen etäisyyden ja oman koskemattomuutensa. Jonkinlainen jäyhä eleettömyys "ei tehrä tästä ny numeroo" -tyyliin tekee kirjoittajan omasta henkilökuvasta aidon. Hän ei melskaa teoillaan eikä tee itsestään sankaria.

Mutta Suoranta on koko ajan myös tiedemies, kasvatuksen, median ja yhteiskunnan tutkija, jonka oma tutkimusalue siten koskettaa tätä hänen henkilökohtaista toimintaansa. Hän tuo esille yhä uusia yhteiskuntatieteen nykyklassikoita ja uusia nimiä, jopa niin että yhteiskuntateorian nykysuuntauksiin perehtymättömälle tätä aineistoa tulee ehkä turhankin paljon ja nopeasti.

Ulkokohtaista oppineisuuden esittelyä kirja ei kuitenkaan ole, vaan Suoranta valottaa omia havaintojaan ja pohdiskelujaan muiden tutkijoiden näkemyksillä. Keskeiseen asemaan nousee moraalinen pohdiskelu, joka on kirjan vahvimpia alueita.

Suorannan lähtökohta on yk- 
sinkertainen lähimmäisenrakkaus, siis inhimillinen perusetiikka jonka mukaan hädässä olevaa on autettava. Lisäksi ihmisten kulttuurin tuottamaa hyvää on pyrittävä jakamaan edes jossain määrin tasapuolisesti kaikille, kansallisuudesta ja muista asioista riippumatta. Voisikin ajatella, että yhteiskuntateoreetikkojen esittelyn sijaan kirjassa olisi käyty vielä enemmän keskustelua myös moraalifilosofian klassisten perinteiden ja näkökulmien kanssa.

Sekä tapahtumien käytännön kulku että periaatteellinen pohdinta johdattavat Suorannan yhä uudestaan tekemisiin kirkon ja uskonnollisten yhdyskuntien käytännön samoin kuin uskonnon perusteidenkin kanssa. Suoranta ei kuulu kirkkoon ja arvioi sen toimintaa paikoin kitkerästikin, mutta päällimmäisenä on silti vilpitön etsijän ja keskustelijan mieli. Itse asiassa Suoranta on tavattoman pitkälle sisäistänyt juuri kristillisen etiikan ja kirja osoittaa, miten vahva tekijä tuo etiikka on koko suomalaisen yhteiskunnan toimivana perustana.

Oma mielenkiintoinen juonteensa onkin keskustelu suomalaisuudesta ja kansallisuudesta. Tässäkin asiassa Suoranta suhtautuu penseästi nationalismiin ja ahtaaseen isänmaallisuuteen, mutta hänen syvemmät pohdintansa osoittavat, että idea kansallisesta kulttuurista ei todellakaan ole vain satunnaisesti sepitetty kertomus. Suomalaisuus on jotain hyvin todellista, niin helppo kuin kulttuurintutkijoiden nyt sitä onkin pintaliitäjinä riepotella.

\section{Auttamisen rohkeus}

Ja tietysti mukana on sitten vie- lä Ashrafin tarina ja hänen näkökulmansa. Sitä ei korosteta, Suoranta ei haluakaan suuresti selvittää pojan taustoja sillä hänen tehtävänsä on auttaa poikaa tässä ja nyt. Mutta juuri tietynlaisen niukkuuden kautta piirtyy koskettava kuva kotimaassaan ja pitkällä pakomatkalla kovia kokeneesta nuorukaisesta, joka lopulta on pääsemässä uudenlaisen elämän alkuun.

Suoranta on halunnut kirjallaan rohkaista ihmisiä tekemään jotain lähimmäistensä auttamiseksi. Oman valinnan ja toiminnan perinpohjainen ja rehellinen kuvaus on hyvä keino tällaisessa asiassa. Voi olla, että kirja panee lukijan jopa miettimään, olisiko minusta lainkaan tuohon. Suorannan ammatillinen asema ja esimerkiksi mediamaailman tuntemus tuokin hänelle tiettyjä käytännön etuja Ashrafin asian hoitamisessa. Silti kyse ei ole siitä, että Suoranta käyttäisi suhteitaan tai että hän professorismiehenä olisi jotenkin etuoikeutetussa asemassa auttamaan lähimmäistä.
Tietysti ihmisen täytyy päätöstä tehdessään harkita, kykeneekö hän seisomaan päätöksensä takana ja vastaamaan asioista, joihin on ryhtymässä. Kirja kuitenkin osoittaa, että päätöksen tulevia seurauksia ei koskaan voi tietää. Kirja onkin hyvä esimerkki rohkeasta asenteesta: kun oma ratkaisu johdattaa aivan uusien ongelmien eteen, niin asioista on vain otettava selvä ja koetettava toimia sitten rationaalisesti, oman selkeän tunteen ja ennen muuta moraalisen näkemyksen pohjalta. Ilmeisesti myös auttamiseen ja moraaliseen toimintaan voi ainakin jossain määrin soveltaa sitä kuuluisaa periaatetta asiallisten hommien hoitamisesta ja Ellun kanoista. Hyvät teot ovat myös yhtä lailla arvokkaita, ovat ne sitten suurempia tai pienempiä.

Tietokirjana ja pamflettina nyky-Suomesta ja ihmisyydestä tämä kauniisti ja taitavasti kirjoitettu pieni kirja on aivan mahdottoman komea suoritus.

\section{Eero Ojanen}

\section{Mediavaikuttamisen keinot}

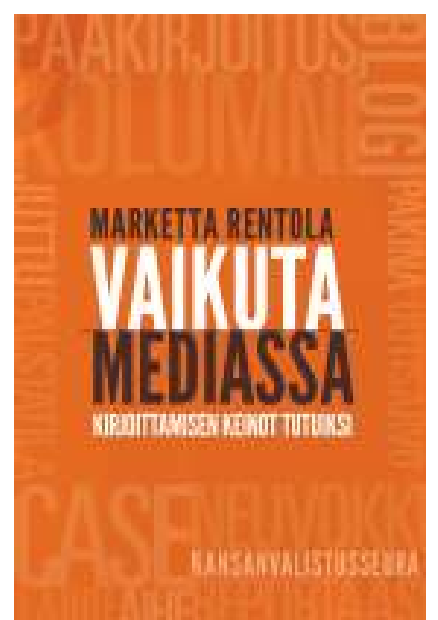

Vaikuta Mediassa -kirja esittelee lukijalle mediakirjoittamisen toimintaperiaatteita ja juttutyyppejä. Viestintäkouluttaja Marketta Rentola kertoo, millaisia kirjoittamisen keinoja lehdet suosivat ja mistä se johtuu. Käytännönläheinen kirja antaa välineitä tekstien purkamiseen.

Kansanvalistusseura 2010. 196 sivua, ovh 32 euroa.

www.kansanvalistusseura.fi 